\title{
Investigating Preferences for the Local Delivery of Agri-Environment Benefits
}

\section{Guy Garrod ${ }^{1}$, Eric Ruto ${ }^{1}$, Ken Willis ${ }^{2}$ and Neil Powe ${ }^{2}$}

${ }^{1}$ Centre for Rural Economy, School of Agriculture, Food and Rural Development, Newcastle University, Newcastle upon Tyne, NE1 7RU, UK

${ }^{2}$ Centre for Research in Environmental Appraisal and Management, School of Architecture, Planning and Landscape, Newcastle University, Newcastle upon Tyne, NE1 7RU, UK

\begin{abstract}
Since 2005, Environmental Stewardship (ES) has been the principal agri-environment scheme for England and is the key instrument for the delivery of increased environmental benefits from agricultural landscapes. The main objective of this study is to investigate the hypothesis that individuals have greater relative preferences for the environmental benefits associated with agri-environment schemes when they are delivered within those landscapes closest to where they live. A choice experiment approach based on a national survey was used to provide data and a mixed logit approach was then used to model relative preferences for the environmental benefits of ES across five generic landscape types. Results showed that most respondents have a preference for benefits to be delivered in those areas closest and most accessible to where they live.
\end{abstract}

Keywords: Agri-environment; Environmental Stewardship; choice experiments; mixed logit 


\section{INTRODUCTION}

A number of previous studies have demonstrated that there may be a relationship between public preferences for environmental goods and services and the locations in which they are delivered (e.g. Purcell et al., 1994; Hunziker, 1995; Dramstad et al., 2006; Brouwer et al., 2010; Lokocz et al., 2011). Based on this premise, this paper investigates the hypothesis that individuals have greater relative preferences for the environmental benefits associated with agri-environment schemes (AESs) when they are delivered within those landscapes closest to where they live.

If there is evidence to support this hypothesis, then this would suggest that greater attention should be paid to the potential for such schemes to generate their intended environmental benefits closer to centres of population. This would have implications for the design and implementation of AESs, for example, in terms of the trade-offs that might be required between increasing the provision of ecosystems services and improving opportunities for the general public to experience these services closer to their homes.

The environmental benefits examined by this study are those associated with the successful implementation of England's principal AES, Environmental Stewardship (ES). Introduded in 2005, this is a two-tier scheme with the primary objectives of maintaining and enhancing the production of non-market goods and services including wildlife conservation, landscape quality and character, protection of the historic environment, resource protection and promotion of public access (Natural England, 2011a). It has four main strands: Entry Level Stewardship (ELS) (including Upland ELS introduced in 2010) is designed to provide a basic ('broad and shallow') level of environmental benefits above those supplied by cross-compliance measures associated with Pillar 1 Common Agricultural Policy (CAP) support under the European Union's Single Payment Scheme (see Hodge and Reader, 2010). Entry to ELS is non-competitive and it is open to all farmers and land managers, who then have a free choice from a menu of environmental management options, each of which is allocated a number of 'points' (Natural England, 2011a). Entry is achieved by reaching a points threshold, and payments are set at a standard rate per hectare.

Higher Level Stewardship (HLS) is open to those farmers who want to deliver higher levels of environmental management on land of particular environmental value. In contrast to ELS, each HLS management option has a separate payment associated with it leading to heterogeneity of per hectare payments (Field et al., 2011; Natural England, 2011). Entry to HLS is competitive and targeted and, if successful, results in the award of a highly specific 10-year management agreement. Organic Entry and Higher Level Stewardship (OELS) provide equivalent schemes for farmers registered with an organic inspection body (Natural England, 2011).

While a number of studies have investigated the contribution that the HLS element of ES has made to various aspects of environmental management (e.g. Boatman et al., 2008; Davey et al., 2010; Ewald et al., 2010; Field et al., 2011), this paper concentrates on whether or not the public prefers this management to be delivered closer to where they live. As such, this is one of a growing number of studies that have used economic techniques, such as choice experiments and contingent valuation, to investigate the environmental benefits associated with changes to the management 
of agricultural landscapes (e.g. Drake, 1992; Willis et al., 1995; Pruckner, 1995; Gonzalez and Leon, 2003; Campbell, 2007; Hanley et al., 2007; Kallas et al., 2007; Arriaza et al., 2008; Johns et al., 2008; Haile and Slangen, 2009; Ruto and Garrod, 2009; Boatman et al., 2010; Hynes et al., 2011).

Here a questionnaire survey is used to explore public preferences for the benefits associated with the implementation of ES across five broad landscape types. The scenario provided to survey respondents assumes that the target levels of farmer participation in the scheme will be achieved in 2013, as planned by the UK Department of Environment, Food and Rural Affairs (Defra) and that these levels of uptake will deliver a given magnitude and distribution of environmental and other benefits that is described in detail in the questionnaire.

Given that these benefits are planned rather than actual, the preferences elicited by this study are based on the hypothetical delivery of future environmental benefits. Even so, this scenario will allow us to investigate public preferences for where those benefits should be delivered. To achieve this, a choice experiment is used to investigate relative preferences for ES benefits across the various landscape types. The analysis of choice data linked to information about respondents' proximity to the different landscape types allows us to test the main hypothesis of the study.

This analysis and the underlying survey instrument assumes that most respondents will regard the adaptations to landscapes delived by ES as beneficial. While this assumption is rather leading, it mirrors the objectives of the scheme, in as much as ES is designed to deliver what the UK Government and many experts consider to be a important set of environmental benefits across English agricultural landscapes. The information provided to respondents in the questionniare survey clearly depicts the main changes arising as a result of ELS and HLS, both at a landscape level and within particular landscape features, and any respondent who has a negative preference for those changes was able to make choices that relected those views.

\section{METHODS}

\subsection{CHOICE EXPERIMENTS}

Choice experiments (CEs) are a commonly used stated preference methodology for non-market valuation. Using this approach the attributes (and attribute levels) of the good or service being examined are allowed to vary and respondents are asked to state their preferences for various alternative attribute configurations. Respondents' preferences for a particular good are then assumed to be based on their utility for the combination of attributes and attribute levels that it offers.

CEs have been extensively applied to value quality changes in environmental attributes (e.g. Adamowicz et al., 1998; Willis et al., 2002). A notable development is in the use of CEs to evaluate preferences for public policies or programmes aimed at delivering environmental goods, as opposed to valuing changes in environmental goods themselves (e.g. Ruto and Garrod, 2009; Espinosa-Goded et al., 2010). The advantage of a CE approach over a more simple preference based approach is that it requires respondents to make systematic choices. This may provide a more realistic 
estimate of relative preferences than, say, a simple points allocation approach where to simplify their task some respondents may distribute points evenly across options rather than to the options they prefer the most (e.g. landscapes in which they live or visit).

The multinomial logit model (MNL) (McFadden, 1974) is the most commonly used discrete choice model for the analysis of results from CEs. While the relative simplicity of the MNL model is a clear advantage, it has some important limitations. For example, the MNL framework imposes homogenous preferences across respondents and its concomitant assumption of the independence of irrelevant alternatives (IIA) (Hausman and McFadden, 1984). Preferences, however, may be heterogeneous and accounting for the presence of heterogeneity enables computations of unbiased estimates of individual preferences. In this paper, we employ the mixed logit model (also known as the random parameter logit model), one of several recent innovations aimed at accounting for preference heterogeneity in choice models (McFadden and Train, 2000). The mixed logit model accounts for preference heterogeneity by allowing utility parameters to vary randomly (and continuously) over individuals and is also not subject to the IIA assumption inherent in the standard MNL. Recent applications of the mixed logit model in the evaluation of benefits of environmental polices include Achnicht (2011); Espinosa-Goded et al. (2011); Ruto and Garrod (2009); and Campbell (2007).

\subsection{SURVEY METHODS}

The questionnaire was extensively piloted and pre-tested in a process that included six focus groups (two each in Beaconsfield, Carslisle and Newcastle, covering a range of socio-economic groups), twelve verbal protocol interviews and a pilot survey of 103 individuals in nine locations across England. This process allowed the questionnaire design to be validated and confirmed that respondents could assimilate and interpret the high volume of mainly visual information (with supporting text) explaining the operation and benefits of ES and the differences in the environmental benefits provided across the five landscape types reported in Table 1. Respondents were provided with visual information on the distribution and area of land in each landscape type using a map as shown in Figure 1.

\section{TABLE 1 HERE}

\section{FIGURE 1 HERE}

The choice experiment approach was used to explore whether or not respondents' preferences for the benefits associated with ES varied depending on which of the five landscape types they were delivered in. Here, respondents were presented with paired alternatives based on five attributes, each simply denoting the presence or absence of ES benefits in one of the five landscape categories (for an example of a choice card and the attributes used therein, see Figure 2). As the focus of the study was on relative preferences for the provision of ES benefits across landscapes, rather than on 
public willingness to pay for such benefits, no payments attribute was included in the choice alternatives. This permitted respondents to concentrate on where they most preferred these benefits to be generated, rather than on how much they should pay for them. By eliminating the possibility of choices where respondents' decisions might be driven by considerations of cost, rather than where benefits would be generated, this approach provided more information about relative preferences for the spatial distribution of ES benefits.

\section{FIGURE 2 HERE}

Respondents were asked to choose their preferred alternative from each pair and repeated choices then reveal their preferences for ES benefits in different landscapes. To limit the cognitive burden on respondents no more than four choice cards were presented to each respondent. The number of choice cards was decided upon following extensive pre-testing. Choice cards were selected at random from a set of 28 generated using a fractional factorial experimental design.

This approach is an example of the growing use of choice experiments to derive utility weights for a good across its attributes in order to investigate relative preferences rather than to place a value on them. As such, this approach is similar to that adopted by Morey et al. (2008) to investigate preferences for landscape preservation. In that paper, attitudinal data was used to derive latent class membership to help explain variation in WTP elicited from an earlier CV question. A utility scale was also employed by Sayadi et al. (2005) to assess preferences for agrienvironmental attributes in the Alpurjarran landscape of south-eastern Spain.

Choice of alternative is modelled as a function of the attributes of the various alternatives offered (i.e. the provision of ES benefits in the five different landscapes). The analysis of choices allows the marginal utility of ES benefits in different landscapes to be estimated. This marginal utility is a measure of the contribution that ES benefits makes to the respondent's well-being.

The sampling strategy adopted in this study concentrated on obtaining a representative socio-demographic mix across both urban and rural areas in England but was also designed to ensure that a representative proportion of respondents was drawn from each of five landscape areas. This study was therefore based on a stratified random sample of households across England. In order to minimise survey costs, the sample was stratified by areas, and a number of randomly selected households were sampled in each area. The sample was also stratified using Defra's Rural and Urban Area Classification (Defra, 2007) at the Office of National Statistics Output Area (OA) level. This ensured that the sample had sufficient representation of households across both rural and urban environments.

For each landscape area the relevant Census OAs were ordered by the strata: Government Office Region and urbanisation (i.e. urban or rural). Additionally they were ordered within the strata by Local Authority area in order to ensure that a geographic spread across England was achieved. For each strata a random start and sampling interval was taken and the OAs were selected using probabilityproportional-to-size (PPS) sampling based on the number of households in each OA. 
There were 180 different sampling points based on OAs, drawn from 160 different local authority areas in England. The sample was representative of urban, town and suburban OAs, and the breadth and variety of the sampling points was designed to reduce any potential bias arising from edge-effects that could occur at those points on the borders between adjacent landscape areas.

The survey generated a total of 1180 usable responses. Over half of respondents came from the Upland \& Upland Fringe and South East Mixed landscapes while only around 10\% came from the Chalk \& Limestone Mixed Landscape. Statistical tests confirmed that the sample was representative according to the parameters used to stratify the population. Before undertaking the choice experiment, all respondents were thoroughly briefed about the five landscape types. This included giving them information about their distribution, character and the environmental and landscape benefits likely to be generated by achieving the target level of participation in both the Entry and Higher-level elements of ES.

\section{RESULTS}

The results of a mixed logit model based on the analysis of 4720 choices generated by the questionnaire survey are reported in Table 2 . The results shows that all five landscapes are highly significant determinants of choice, with the South-East Mixed and Upland \& Upland Fringe landscapes being the most influential and Chalk \& Limestone Mixed the least. The normalised values are provided to give an indication of differences in importance of each of the five landscapes in influencing the selection of the choice alternatives given in the choice experiment. These normalised values are calculated by dividing the coefficient values for all landscapes by the coefficient value of the most valued landscape (i.e. South East mixed). This generates values in a range between 1 and 0 , where 1 indicates the most preferred landscape. Preferences for other landscapes relative to the most preferred landscape can therefore be inferred by inspection of the normalised value, e.g. in Table 2 the preference for ES benefits in the Eastern Arable landscape is shown to be $76.81 \%$ as strong as the preference for ES benefits in the South East Mixed landscape.

\section{TABLE 2 HERE}

The next two models begin to look at the impact that proximity to a given landscape has on the choices being made in the choice experiment. First, we examine the hypothesis that the respondent is more likely to choose an alternative in which ES is operational within their 'home landscape' (i.e. the landscape type where the respondent lives). Such an investigation is possible owing to the design of the choice experiment, in which respondents are required to choose between two alternative hypothetical scenarios in each of which ES is operational in some, but not all, of the five landscape types. Thus, if a respondent has a strong preference for ES benefits in her home landscape, then this preference would be expected to inform her choices. Table 3 reports the results of the mixed logit model where an interaction term is included that takes the value one if the choice alternative includes ES within the respondent's home landscape, and zero otherwise. 
Again, all of the coefficients in this model are positive and highly significant and indicate that the probability of choosing any given alternative in a choice experiment is increased if within it ES is operational within the respondent's home landscape. Examination of the coefficient values in Table 3, allows us to identify that residents in the Western Mixed landscape have the strongest preferences for their home landscape relative to the other landscapes (i.e. for residents if ES is operational in the Western Mixed landscape the relevant coefficient value becomes $0.9795+1.8583$ ), while residents in the South-East Mixed and Chalk \& Limestone Mixed landscapes have the lowest.

\section{TABLE 3 HERE}

This result has been investigated further by splitting the sample into five components according to the respondent's home landscape. Thus, five models were estimated, based on the choices of five separate sets of respondents each of which lives in one of the five different landscape types. Examination of the estimated coefficient values within these five models allows us to identify each set of respondents' relative preferences across all five landscapes including their home landscape. In all of the resulting models, apart from that for the Chalk \& Limestone Mixed landscape (where the home landscape comes second in order of preference to the South East Mixed landscape), models show that respondents have a clear preference for their home landscapes. Table 4 reports the preference ordering for each of these five sub-models and reveals that the ordering of preferences varies considerably across respondents in all five landscape types with several landscapes being ranked anywhere between most and least preferred by respondents located in other landscapes.

\section{TABLE 4 HERE}

The mixed logit model reported in Table 5, takes the investigation of the effect of location on preferences a step further by including interaction terms which a measure how far the respondent lives from the nearest area of a given landscape type. Thus, as well as allowing us to examine whether or not the operation of ES in a particular landscape affects respondents' choices of alternatives within the choice experiment, this model also allows us to examine whether or not choices are also influenced by how far away a respondent lives from the nearest area of a particular landscape type. This therefore extends the analysis of the earlier model by looking at the influence of proximity to all landscape types rather than just the home landscape. Again, all coefficient values are strongly significant. Coefficient values for the five landscape types were all positive, while those for all of the distance interaction terms were, as would be expected, negative. This indicates that the benefits of ES in those landscapes nearest to where respondents live have a greater influence on their choices than those in landscapes which are further away. This distance decay effect is strongest for the Western Mixed landscape and weakest for the South-East Mixed and Upland \& Upland Fringe landscapes. For example, for every additional $10 \mathrm{~km}$ that a respondent lives away from the Western Mixed landscape, respondents' utility for ES benefits decreases by around $6.13 \%$, compared to $1.92 \%$ and $3.21 \%$ for South-East Mixed and Upland \& Upland Fringe landscapes respectively.

\section{TABLE 5 HERE}




\section{CONCLUSIONS}

Negotiations about the future of the CAP after 2013 will shape the countryside of Europe and its rural communities for the remainder of the decade. An important aspect of these negotiations will be the allocation of resources to the second pillar of the CAP and in particular to the funding of the different objectives under that Pillar. In England, the previous Government opted to spend around $80 \%$ of its total rural development budget under the Rural Development Programme for England (RDPE) on agri-environment schemes under Axis 2. While the overall CAP budget and the amount allocated to Pillar 2 activities is likely to change following these negotiations, it remains important to ensure that decision makers have good information upon which to base these allocations. An important aspect of this information is an understanding that the benefits associated with agri-environment schemes are likely to vary depending on where they are generated. This should lead to an acknowledgement that decisions on spending on such schemes could be enhanced by a better understanding of how their benefits differ in the different areas where they are implemented.

This study uses a choice experiment approach to examine preferences for the benefits associated with Environmental Stewardship (ES), the main agri-environment scheme in England and to investigate how these vary across five broad landscape types. Analysis of the choice experiment results demonstrates that respondents have significant preferences for the ES benefits that will be generated in each of the five landscapes being investigated.

Further examination, using samples split according to the home landscape type of respondents, allows us to identify respondents' relative preferences across all five landscapes, including their home landscape. In all cases, apart from the Chalk \& Limestone Mixed landscape, results show that respondents have a clear preference for their home landscapes. This supports the hypothesis that respondents have a higher preference for ES benefits in landscapes similar to those in which they live.

Following the recommendations of Bateman (2009), the study also examined whether or not choices are influenced by how far away a respondent lives from the nearest area of a particular landscape type. Results suggested that the benefits of ES in those landscapes nearest to where respondents live have a greater influence on their choices than those in landscapes which are further away. This distance decay effect is strongest for the Western Mixed landscape and weakest for the South-East Mixed and Upland \& Upland Fringe landscapes.

All of the above suggests that while the general public have positive and significant preferences for ES to generate environmental benefits across all of England, most still have a preference for benefits to be delivered in those areas closest and most accessible to where they live. This suggests that a significant proportion of the benefits associated with the scheme are use benefits. Non-use benefits arising from ES, however, may also be significant in landscapes further away from where people live. 
By demonstrating that the public have higher preferences for ES benefits in their home landscapes, these findings suggest that AES funding could be further targeted to ensure that more land adjacent to, or accessible from, areas of high population is included in the scheme. In their study, Quillérou and Fraser (2010) show that contracts for HLS are allocated to regions of lower payment rates and closer to cities. Coupled with our results, this suggests that the design of HLS is able to allocate contracts to farmers that match social preferences for use benefits. In order to maximize the level of environmental benefits that ES can provide to the public, this indicates that increasing the levels of ES funding to land closest to areas of high population could increase use benefits.

Clearly, a balance is required between targeting of funding linked to key habitats and species priorities (providing a mix of use and non-use benefits) and spending to increase the use benefits that the scheme may have for the general public. Therefore it could be argued that under HLS more effort should be made to engage those farmers with land offering greater access opportunities to the public. An alternative way of ensuring an increase in use benefits would be to allocate a greater proportion of the ES budget to HLS agreements, targeting the additional funding on farms offering the best public access opportunities. Similarly, an increase in the proportion of the remaining ELS funding that is allocated to farms closer to where people live or visit may be justified, especially if that part of the scheme were extended to included some provision for additional public access (as is the case with HLS). Any additional spending could be funded though an increased budget for Pillar 2 of the CAP (perhaps based on further modulation from Pillar 1).

This study raises some interesting issues about spatial heterogeneity of values linked to nature, suggesting that measures offering comparable improvements to the provision of natural capital may be valued differently by the general public depending on where they are delivered. It would therefore seem important to develop research strategies that will allow for a more effective comparison of the potential non-market benefits of environmental management measures with the costs of delivering them, by assessing how the benefits and costs for similar environmental improvements can vary over space. Such information could lead to more cost-effective decisions about programme delivery for agri-environment and other schemes designed to deliver environmental benefits. 


\section{References}

Achtnicht, M. (2011) Do environmental benefits matter? Evidence from a choice experiment among house owners in Germany, Ecological Economics, 70 (11): 21912200

Adamowicz, W. L., Boxall, P. and Louviere, J. (1998) 'Stated preference approaches for measuring passive use values: Choice experiments and contingent valuation', American Journal of Agricultural Economics, 80 (1): 64-75.

Arriaza, M., J.A. Gomez-Limon, Z. Kallas, and O. Nekhay (2008). Demand for Noncommodity Outputs from Mountain Olive Groves. Agricultural Economics Review 9, 5-23.

Bateman, I.J. (2009). Bringing the real world into economic analyses of land use values: incorporating spatial complexity. Land Use Policy 26, S30-S42.

Boatman, N., Ramwell, C., Parry, H., Jones, N., Bishop, J., Gaskell, P., Short, C., Mills, J. and Dwyer, J. (2008) A review of environmental benefits supplied by agrienvironment schemes. No. FST20/79/041. Land Use Policy Group, London.

Boatman, N., Willis, K.G. and Garrod, G.D. and Powe, N.A. (2010). Estimating the wildlife and landscape benefits of Environmental Stewardship. Final Report to Defra. Food and Environment Research Agency, York and the University of Newcastle upon Tyne. Available from:

http://archive.defra.gov.uk/evidence/economics/foodfarm/reports/documents/estimati ngthewildlife.pdf (Last accessed 22/6/11)

Brouwer, R., Martin-Ortega, J. and Berbel, J. (2010). Spatial preference heterogeneity: A Choice Experiment. Land Economics 86, 552-568.

Campbell, D. (2007). Willingness to pay for rural landscape improvements: Combining mixed logit and random-effects models. Journal of Agricultural Economics, 58, 467-483.

Davey, C.M., Vickery, J.A., Boatman, N., Chamberlain, D., Parry, H. and Siriwardena, G.M. (2010). Regional variation in the efficacy of Entry Level Stewardship in England. Agriculture, Ecosystems \& Environment 139, 121-128.

Defra (2007) A Rural/Urban Classification of Parliamentary Constituencies of England and Wales 2007. Defra London. Available from:

http://archive.defra.gov.uk/evidence/statistics/rural/documents/rural-defn/parliaconstituencies-classification.pdf (Last Accessed: 11/6/12)

Drake, L. (1992) The non-market value of the Swedish agricultural landscape. European Review of Agricultural Economics 19, 351-364.

Dramstad, W.E., Tveit, S.M., Fjellstad, W.J., Fry, G.L.A. (2006). Relationships between visual landscape preferences and map-based indicators of landscape structure. Landscape and Urban Planning 78, 465-474. 
Espinosa-Goded, M., Barreilo-Hurle, J. and Ruto, E. (2010) 'What do farmers want from agri-environmental scheme design?' A choice experiment approach', Journal of Agricultural Economics, 61 (2): 259-273.

Ewald, J.A., Aebischer, N.J., Richardson, S.M., Grice, P.V. and Cooke, A.I. (2010). The effect of agri-environment schemes on grey partridges at the farm level in England. Agriculture, Ecosystems and Environment, 138: 55-63.

Field, R.H. , Morris, A.J., Grice' P.V. and Cooke A. (2011). The provision of winter bird food by the English Environmental Stewardship Scheme. Ibis 153, 14-26.

Garrod, G.D. (2009). Greening the CAP: how the improved design and implementation of agri-environment schemes can enhance the delivery of environmental benefits. Journal of Environmental Planning and Management, 52, 571-574.

González, M. and León, C. (2003). Consumption, process and multiple valuation of landscape attributes. Ecological Economics, 45, 159-169.

Haile, D.T. and Slangen, L.H.G. (2009 Estimating the Willingness to Pay for the Benefit of AES Using the Contingent Valuation Method. Journal of Natural Resource Policy Research 1, 139 - 152.

Hanley, N., Colombo, S., Johns, H. and Mason, P. (2007). The reform of support mechanisms for upland farming: Paying for public goods in the severely disadvantaged areas of England, Journal of Agricultural Economics, 58, 433-453.

Hausman, J. and McFadden, D.E. (1984) Specification tests for the multinomial logit model. Econometrica 52, 1219-1240.

Hodge, I. and Reader, M. (2010) The introduction of Entry Level Stewardship in England: Extension or dilution in agri-environment policy? Land Use Policy 27, 270282.

Hunziker, M. (1995). The spontaneous reafforestation in abandoned agricultural lands: perception and aesthetic assessment by locals and tourists. Landscape and Urban Planning 31, 399-410.

Hynes, S., Campbell, D. and Howley, P. (2011). A holistic vs. an attribute-based approach to agri-environmental policy valuation: do welfare estimates differ? Journal of Agricultural Economics 62, 305-329.

Johns, H., N. Hanley, S. Colombo and Ozdemiroglu. E. (2008) Economic Valuation of Environmental Impacts in the Severely Disadvantaged Areas in England. In E. Birol and P. Koundouri (eds.) Choice Experiments Informing Environmental Policy. Edward-Elgar Publishing: Cheltenham.

Kallas, Z., Gómez-Limón, J. A. and Arriaza, M. (2007) Are citizens willing to pay for agricultural multifunctionality? Agricultural Economics, 36, 405-419.

Lokocz' E., Ryan' R.L and Sadler A.J. (2011) Motivations for land protection and 
stewardship: Exploring place attachment and rural landscape character in Massachusetts. Landscape and Urban Planning 65-76.

McFadden, D. and Train, K (2000). 'Mixed MNL models for discrete response', Journal of Applied Econometrics, 15 (5): 447- 470.

McFadden, D. (1974). Conditional logit analysis of qualitative choice behaviour', in P. E. Zarembka (ed.), Frontiers of Econometrics, Academic Press, New York.

Morey, E., Thiene M., de Salvo M., and Signorello G. (2008). Using attitudinal data to identify latent classes that vary in their preferences for landscape preservation. Ecological Economics 68, 536-546.

Natural England (2011). Look After Your Land with Environmental Stewardship. NE124. Natural England, London. Available from:

http://naturalengland.etraderstores.com/NaturalEnglandShop/NE124. Last accessed 21/6/11.

Pruckner, G. J. (1995). Agricultural landscape cultivation in Austria: An application of the CVM. European Review of Agricultural Economics, 22, 173-190.

Purcell, A.T., Lamb, R.J., Peron, E.M., Falchero, S. (1994). Preference or preferences for landscape. Journal of Environmental Psychology 14, 195-209.

Quillérou, E. and Fraser, R.W. (2010). Adverse selection in the Environmental Stewradship Scheme: Does the Higher level Stewardship scheme design reduce adverse selection? Journal of Agricultural Economics 61, 369-380.

Ruto, E. and Garrod, G.D. (2009). Investigating farmers' preferences for the design of agri-environment schemes: a choice experiment approach. Journal of Environmental Planning and Management, 52, 631-647.

Sayadi, S., Gonlazez Roa M.C., and Requena J.C. (2005). Ranking versus scale rating in conjoint analysis: evaluating landscapes in mountainous regions in southeastern Spain. Ecological Economics 55, 539-530.

Willis, K. G., McMahon, P. L., Garrod, G. D. and Powe, N. A. (2002) 'Water companies' service performance and environmental trade-offs', Journal of Environmental Planning and Management, 45, 363-379.

Willis, K.G., Garrod, G.D. and Saunders, C.M. (1995). Benefits of Environmentally Sensitive Area Policy in England: A Contingent Valuation Assessment. Journal of Environmental Management 44, 105-125. 


\section{Figure 1: Distribution of Landscape Types}

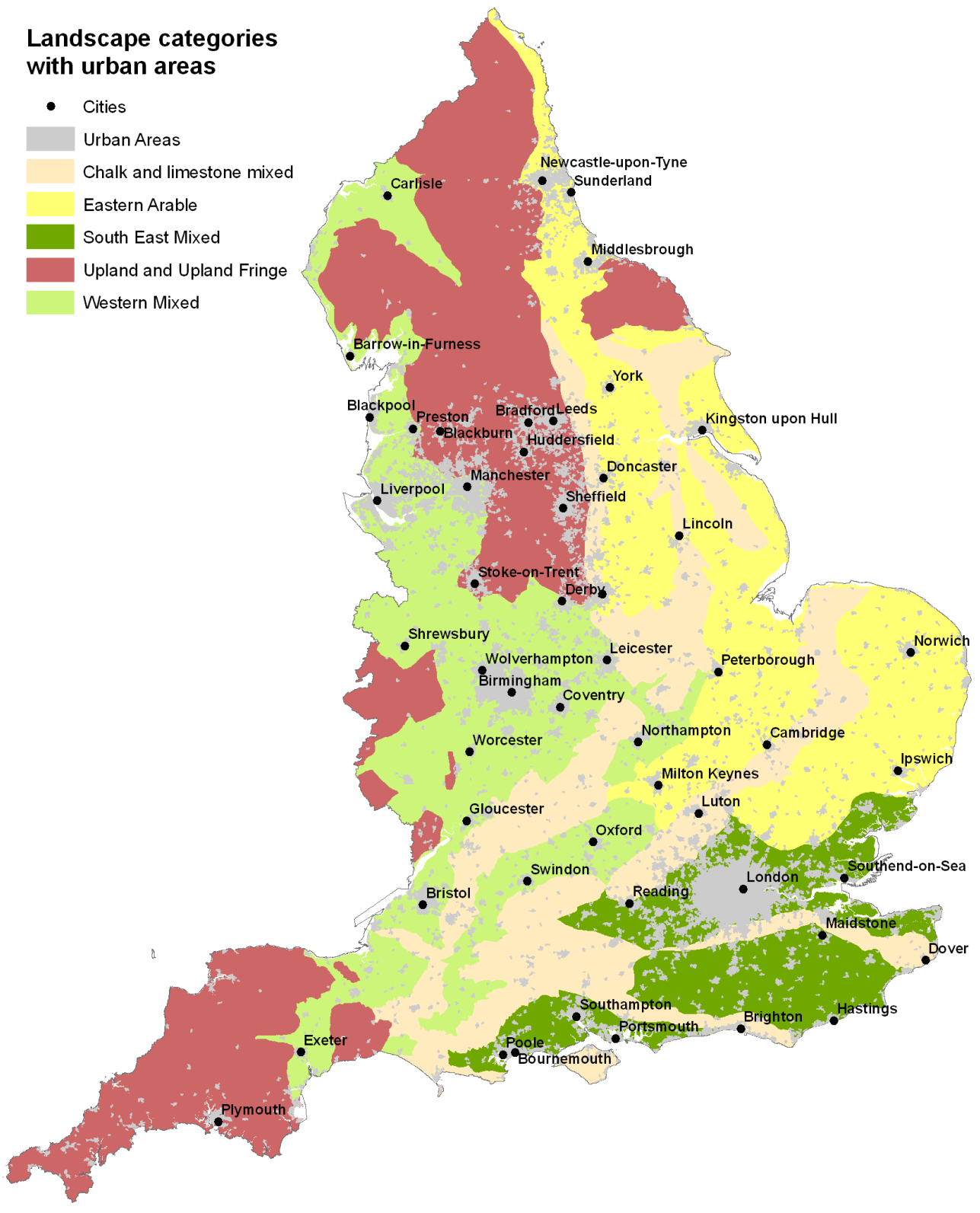


Figure 2: Example of choice cards

CHOICE 2: CHOOSE OPTION A OR B

\begin{tabular}{|c|c|c|}
\hline & $\begin{array}{c}\text { OPTION } \\
\text { A }\end{array}$ & $\begin{array}{c}\text { OPTION } \\
\text { B }\end{array}$ \\
\hline $\begin{array}{c}\text { LANDSCAPE } 1 \\
\text { CHALK \& LIMESTONE } \\
\text { MIXED }\end{array}$ & & ES \\
\hline $\begin{array}{c}\text { LANDSCAPE } 2 \\
\text { EASTERN } \\
\text { ARABLE }\end{array}$ & ES & \\
\hline $\begin{array}{c}\text { LANDSCAPE } 3 \\
\text { SOUTH EAST MIXED } \\
\text { (WOODED) }\end{array}$ & & ES \\
\hline $\begin{array}{r}\text { LANDSCAPE } 4 \\
\text { WESTERN MIXED }\end{array}$ & ES & \\
\hline $\begin{array}{l}\text { LANDSCAPE } 5 \\
\text { UPLAND AND UPLAND } \\
\text { FRINGE }\end{array}$ & & ES \\
\hline
\end{tabular}




\section{Chalk \& Limestone Mixed Farming}

In general the landscapes are open with rolling hills and relatively low amounts of woodland. They are predominantly rural, with only $6 \%$ of land classified as urban. On average, around two thirds of the agricultural land is occupied by farms growing mainly crops, the remainder being split between dairy farms, farms with sheep and beef cattle, and mixed farms with both crops and livestock. Farms specialising in pigs, poultry and horticulture cover only a very small proportion of the land area. Cropping is mainly of cereals and other 'combinable' crops such as oilseed rape and peas, with few root crops (potatoes, sugar beet etc.) in most areas.

\section{Eastern Arable}

The landscapes are generally flat and low lying, and in some areas such as the Fens and Humberhead levels, occupy former wetlands. Here drainage ditches or dykes often separate the fields rather than hedges. The soils are often of good quality and high yielding, and for this reason, over $80 \%$ of the agricultural area is devoted to farms dominated by cropping, with the widest range of different crops being grown in these areas, though the area of horticultural crops is limited. Because the land has a high value for growing crops, the area of woodland is limited, and there are few livestock farms. The landscapes remain predominantly rural, with only around $8 \%$ of the area classified as urban.

\section{South East Mixed (wooded)}

Soil types are predominantly sand or clay. A high proportion (over 20\%) of the land is urban or suburban. There is also a high proportion of woodland relative to the other landscape types. The agriculture is varied and diverse, with around $45 \%$ of the agricultural area taken up by crop-dominated farms, $20 \%$ by livestock farms, and $9 \%$ by mixed farms. Much of the landscape is a patchwork of farmland, woodland and settlements, with fields often small and surrounded by hedgerows. This landscape type also has the highest area of land devoted to horticultural farms (4\%), and orchards are common in Kent. Nineteen percent of the area is taken up by 'other' farm types, most of which are smallholdings or other small non-commercial or hobby farms.

\section{Upland and Upland Fringe}

The poor soils, uneven topography and cool wet climate mean that upland areas are generally unsuited to arable cropping, so farming is predominantly pastoral. Over $60 \%$ of the area is devoted to grazing livestock, with a further $9 \%$ taken up by mixed farms. Crop-dominated farms cover only around $13 \%$ of the area. Landscapes are generally open on the hills, with vegetation composed of heather, bracken and rough grasses. Fields of improved grass ('in-bye' land) are found on the lower slopes and valleys, divided predominantly by stone walls. Broadleaved or deciduous woodland is scarce on the open moors, but is more frequent in steep-sided valleys. In some areas there are also have large blocks of coniferous forestry plantations. Urbanised areas cover around 5\% of the landscape type, most of this being accounted for by the industrial conurbations of West Yorkshire and Derbyshire. Away from these areas, 
the uplands are sparsely populated.

\section{Western Mixed}

Generally low-lying, these are typically a pastoral landscapes, though around $13 \%$ of the land area is urban, including the conurbations centred around Birmingham, Manchester and Liverpool. Fields are divided by hedges, often containing mature trees. Much of the land is devoted to livestock enterprises, though over a third of the area is still taken up with farms classified as arable or general cropping, and a further $10 \%$ classified as mixed. This landscape type has more dairy farming than any other, with nearly $20 \%$ of the land area devoted to dairy farms. A further $17 \%$ of the land area is taken up by lowland grazing livestock (cattle and sheep) farms. Hops and orchards are found in the Herefordshire area. 
Table 2 Baseline mixed logit estimates from experiment

\begin{tabular}{|c|c|c|c|}
\hline Attribute & $\begin{array}{l}\text { Coefficient } \\
\text { (normalised value) }\end{array}$ & Std. Error & p-value \\
\hline $\begin{array}{l}\text { ES Operational in Chalk } \\
\text { \& Limestone Mixed }\end{array}$ & $\begin{array}{l}1.1079 \\
(0.6190)\end{array}$ & 0.1119 & 0.000 \\
\hline $\begin{array}{l}\text { ES Operational in } \\
\text { Eastern Arable }\end{array}$ & $\begin{array}{l}1.3748 \\
(0.7681)\end{array}$ & 0.1274 & 0.000 \\
\hline $\begin{array}{l}\text { ES Operational in South- } \\
\text { East Mixed }\end{array}$ & $\begin{array}{l}1.7898 \\
(1)\end{array}$ & 0.1388 & 0.000 \\
\hline $\begin{array}{l}\text { ES Operational in } \\
\text { Western Mixed }\end{array}$ & $\begin{array}{l}1.6187 \\
(0.9044) \\
\end{array}$ & 0.1357 & 0.000 \\
\hline $\begin{array}{l}\text { ES Operational in } \\
\text { Upland \& Upland Fringe }\end{array}$ & $\begin{array}{l}1.6438 \\
(0.9184)\end{array}$ & 0.1378 & 0.000 \\
\hline \multicolumn{4}{|c|}{ Standard deviations of parameter distribution* } \\
\hline $\begin{array}{l}\text { ES Operational in Chalk } \\
\text { \& Limestone Mixed }\end{array}$ & 1.9286 & 0.1700 & 0.000 \\
\hline $\begin{array}{l}\text { ES Operational in } \\
\text { Eastern Arable }\end{array}$ & 2.5417 & 0.2054 & 0.000 \\
\hline $\begin{array}{l}\text { ES Operational in South- } \\
\text { East Mixed }\end{array}$ & 2.4955 & 0.1864 & 0.000 \\
\hline $\begin{array}{l}\text { ES Operational in } \\
\text { Western Mixed }\end{array}$ & 2.5119 & 0.2025 & 0.000 \\
\hline $\begin{array}{l}\text { ES Operational in } \\
\text { Upland \& Upland Fringe }\end{array}$ & 2.5022 & 0.2078 & 0.000 \\
\hline Log-likelihood & -3368.188 & & \\
\hline McFadden Pseudo $R^{2}$ & 0.351 & & \\
\hline$n($ respondents $)$ & 1180 & & \\
\hline$N($ choices $)$ & 4720 & & \\
\hline
\end{tabular}

Notes: all coefficients were entered as random parameters assuming a normal distribution 
Table 3 Mixed logit model incorporating home landscape of respondent as an interaction term

\begin{tabular}{llll}
\hline Attribute & Coefficient & Std. Error & p-value \\
\hline $\begin{array}{l}\text { ES Operational in Chalk \& Limestone } \\
\text { Mixed }\end{array}$ & 0.9510 & 0.1179 & 0.000 \\
\hline ES Operational in Eastern Arable & 1.1535 & 0.1342 & 0.000 \\
\hline ES Operational in South-East Mixed & 1.5247 & 0.14412851 & 0.000 \\
\hline ES Operational in Western Mixed & 0.9795 & 0.1461 & 0.000 \\
\hline $\begin{array}{l}\text { ES Operational in Upland \& Upland } \\
\text { Fringe }\end{array}$ & 1.3055 & 0.1362 & 0.000 \\
\hline $\begin{array}{l}\text { ES Operational in Chalk \& Limestone } \\
\text { Mixed* Respondent lives in that } \\
\text { landscape }\end{array}$ & 1.3109 & 0.3425 & 0.000 \\
\hline $\begin{array}{l}\text { ES Operational in Eastern } \\
\text { Arable*Respondent lives in that } \\
\text { landscape }\end{array}$ & 1.4459 & 0.3139 & 0.000 \\
\hline $\begin{array}{l}\text { ES Operational in South-East Mixed* } \\
\text { Respondent lives in that landscape }\end{array}$ & 0.7730 & 0.2490 & 0.002 \\
\hline $\begin{array}{l}\text { ES Operational in Western Mixed* } \\
\text { Respondent lives in that landscape }\end{array}$ & 1.8583 & 0.2616 & 0.000 \\
\hline $\begin{array}{l}\text { ES Operational in Upland \& Upland } \\
\begin{array}{l}\text { Fringe* Respondent lives in that } \\
\text { landscape }\end{array}\end{array}$ & 1.5177 & 0.3444 & 0.000 \\
\hline
\end{tabular}

landscape

\section{Standard deviations of parameter distributions*}

\begin{tabular}{llll}
\hline $\begin{array}{l}\text { ES Operational in Chalk \& Limestone } \\
\text { Mixed }\end{array}$ & 1.9414 & 0.1782 & 0.000 \\
\hline ES Operational in Eastern Arable & 2.6022 & 0.2025 & 0.000 \\
\hline ES Operational in South-East Mixed & 2.5485 & 0.2058 & 0.000 \\
\hline ES Operational in Western Mixed & 2.4478 & 0.2001 & 0.000 \\
\hline $\begin{array}{l}\text { ES Operational in Upland \& Upland } \\
\text { Fringe }\end{array}$ & 2.4995 & 0.2061 & 0.000 \\
\hline
\end{tabular}

\begin{tabular}{ll}
\hline Log-likelihood & -3338.253 \\
\hline McFadden Pseudo $R^{2}$ & 0.356 \\
\hline$n$ (respondents) & 1180 \\
\hline$N$ (choices) & 4720
\end{tabular}

Notes: all coefficients were entered as random parameters assuming a normal distribution, except the interactions with home landscape which were specified as fixed parameters. The standard deviations of the distribution of interaction parameters were not significant in a model in which all parameters were specified as random. 
Table 4 Preference Ordering for Landscape specific RPL Models

\begin{tabular}{lccccc}
\hline & $\begin{array}{c}\text { Choice } \\
\text { Model for } \\
\text { Chalk \& } \\
\text { Limestone } \\
\text { Mixed } \\
\text { Residents }\end{array}$ & $\begin{array}{c}\text { Choice } \\
\text { Model for } \\
\text { Eastern } \\
\text { Arable } \\
\text { Residents }\end{array}$ & $\begin{array}{c}\text { Choice } \\
\text { Model for } \\
\text { South-East } \\
\text { Mixed } \\
\text { Residents }\end{array}$ & $\begin{array}{c}\text { Choice } \\
\text { Model for } \\
\text { Western } \\
\text { Mixed } \\
\text { Residents }\end{array}$ & $\begin{array}{c}\text { Choice } \\
\text { Model for } \\
\text { Upland \& } \\
\text { Upland } \\
\text { Fringe } \\
\text { Residents }\end{array}$ \\
\hline $\begin{array}{l}\text { Chalk \& } \\
\text { Limestone }\end{array}$ & 2 & 3 & 1 & 4 & 5 \\
Mixed & & 1 & 4 & 5 & 2 \\
\hline $\begin{array}{l}\text { Eastern } \\
\text { Arable }\end{array}$ & 3 & 2 & 1 & 5 & 3 \\
\hline $\begin{array}{l}\text { South-East } \\
\text { Mixed }\end{array}$ & 4 & 4 & 3 & 1 & 2 \\
\hline $\begin{array}{l}\text { Western } \\
\text { Mixed }\end{array}$ & 5 & 2 & 3 & 4 & 1 \\
\hline $\begin{array}{l}\text { Upland \& } \\
\text { Upland }\end{array}$ & 5 & & & & \\
Fringe & & & & & \\
\hline
\end{tabular}


Table 5 RPL Model Incorporating Distance of Respondent from Nearest Area of Each Landscape Type

\begin{tabular}{llll}
\hline Attribute & Coefficient & Std. Error & p-value \\
\hline $\begin{array}{l}\text { ES Operational in Chalk \& Limestone } \\
\text { Mixed }\end{array}$ & 1.2571 & 0.1519 & 0.000 \\
\hline ES Operational in Eastern Arable & 1.9401 & 0.1848 & 0.000 \\
\hline ES Operational in South-East Mixed & 2.1679 & 0.1866 & 0.000 \\
\hline ES Operational in Western Mixed & 2.0961 & 0.1734 & 0.000 \\
\hline $\begin{array}{l}\text { ES Operational in Upland \& Upland } \\
\text { Fringe }\end{array}$ & 2.1730 & 0.2043 & 0.000 \\
\hline $\begin{array}{l}\text { ES Operational in Chalk \& Limestone } \\
\text { Mixed* Distance from that landscape }\end{array}$ & -0.0060 & 0.0033 & 0.068 \\
\hline $\begin{array}{l}\text { ES Operational in Eastern Arable* } \\
\text { Distance from that landscape }\end{array}$ & -0.0097 & 0.0022 & 0.000 \\
\hline $\begin{array}{l}\text { ES Operational in South-East Mixed* } \\
\text { Distance from that landscape }\end{array}$ & -0.0042 & 0.0010 & 0.002 \\
\hline $\begin{array}{l}\text { ES Operational in Western Mixed* } \\
\text { Distance from that landscape }\end{array}$ & -0.0128 & 0.0026 & 0.000 \\
\hline $\begin{array}{l}\text { ES Operational in Upland \& Upland } \\
\text { Fringe* Distance from that landscape }\end{array}$ & -0.0070 & 0.0017 & 0.000 \\
\hline \multicolumn{1}{c}{ Standard deviations of parameter distributions* } & \\
\hline $\begin{array}{l}\text { ES Operational in Chalk \& Limestone } \\
\text { Mixed* Distance from that landscape }\end{array}$ & 2.0227 & 0.1769 & 0.000 \\
\hline $\begin{array}{l}\text { ES Operational in Eastern Arable* } \\
\text { Distance from that landscape }\end{array}$ & 2.3066 & 0.1819 & 0.000 \\
\hline $\begin{array}{l}\text { ES Operational in South-East Mixed* } \\
\text { Distance from that landscape }\end{array}$ & 2.3011 & 0.2071 & 0.000 \\
\hline $\begin{array}{l}\text { ES Operational in Western Mixed* } \\
\text { Distance from that landscape }\end{array}$ & 2.2824 & 0.1990 & 0.000 \\
\hline $\begin{array}{l}\text { ES Operational in Upland \& Upland } \\
\text { Fringe* Distance from that landscape }\end{array}$ & 2.5925 & 0.2143 & 0.000 \\
\hline
\end{tabular}

\begin{tabular}{ll}
\hline Log-likelihood & -3117.664 \\
\hline McFadden Pseudo $R^{2}$ & 0.362 \\
\hline$n$ (respondents) & 1180 \\
\hline$N$ (choices) & 4720 \\
\hline
\end{tabular}

Notes: all coefficients were entered as random parameters assuming a normal distribution, except the interactions with distance from landscape which were specified as fixed parameters. The standard deviations of the distribution of interaction parameters were not significant in a model in which all parameters were specified as random. 